Relations industrielles

Industrial Relations

\title{
Labor in the South, by F. Ray Marshall, Harvard University Press, Cambridge, Massachusetts, 1967, 460 pages.
}

\section{L.-René Parenteau}

Volume 23, numéro 1, 1968

URI : https://id.erudit.org/iderudit/027889ar

DOI : https://doi.org/10.7202/027889ar

Aller au sommaire du numéro

Éditeur(s)

Département des relations industrielles de l'Université Laval

ISSN

0034-379X (imprimé)

1703-8138 (numérique)

Découvrir la revue

Citer ce compte rendu

Parenteau, L.-R. (1968). Compte rendu de [Labor in the South, by F. Ray

Marshall, Harvard University Press, Cambridge, Massachusetts, 1967, 460

pages.] Relations industrielles / Industrial Relations, 23(1), 187-187.

https://doi.org/10.7202/027889ar

Tous droits réservés @ C Département des relations industrielles de l'Université Laval, 1968
Ce document est protégé par la loi sur le droit d'auteur. L’utilisation des services d'Érudit (y compris la reproduction) est assujettie à sa politique d'utilisation que vous pouvez consulter en ligne.

https://apropos.erudit.org/fr/usagers/politique-dutilisation/ 
connues sur le physique et le psychique humain pour les rechercher dans le fonctionnement et les caractéristiques qui se rapportent à une activité du travail. Par activité du travail, l'auteur entend toute activité qui demande un effort quelconque.

L'auteur, après avoir posé les caractéristiques de la mécanisation et de l'automation, étudie le comportement de l'appareil humain ou contact de la machine, il insiste davantage sur l'activité des muscles et sur la production d'énergie nécessaire ò l'exécution des tâches. A cela, il ajoute les facteurs et les conditionnements de l'adaptation à ces nouveaux champs de l'activité humaine. Dans les chapîtres postérieurs, il aborde des problèmes très contemporains du travail automatisé, soit l'information et l'entraînement. Pour l'information, il donne quelques conditions essentielles pour qu'elle soit facilement soisie et pour qu'elle entraine les réactions voulues de la part de l'exécutant. Les problèmes de l'entraînement font le sujet d'une cnalyse résumée de la qualification professionnelle et des difficultés qui surgissent dans la détermination des caractéristiques d'une tôche à apprendre.

Enfin, un dernier chapitre traite de I' * Ergonomie » comme telle. Le terme est né de la nécessité de décrire l'étude scientifique de l'homme et de son travail, étude qui est en fait la rencontre de plusieurs sciences connexes. Son domaine recouvre l'ensemble des * aspects physiologiques, anotomiques, psychologiques de l'homme dans son ambiance de travail ».

\section{L.-René PARENTEAU}

Labor in the South, by F. Ray Marshall, Harvard University Press, Cambridge, Massachusetts, 1967, 460 pages.

This history of Labor in the South of the United States retains the major phases, lines and problems of labor in America and adds the particularities of its evolution in the south. It is more than narrative. It analyzes the numerous relations between industrialization and union growth, between economic, political and social institutions. The study is completed with a good deal of historical and statistical notes.

Professor Marshall explains two major foctors of slow organization of labor in the south:

1) an external factor or the lasting rivalry between the north and the south, and the colonial economy of the south;
2) an internal factor or the racial problem and the class problem between rich and poor white peoples. Many secondary problems come after: the traditional structure of the south, slavery, control of politics by big planters and cotton millers, slow development of industrialization and so on.

The history is the sum of repeated organizing efforts by the Knights of Labor the Communists, the Socialists, the International Unions and then by the AFL-CIO (Operation Dixie).

In the last chapters, the author tries to forecast the conditions of the evolution to come. He states that too many studies fail to prove the important effects of legislation on union growth, especially the effects of the right-to-work laws. The influence of the community, the change in the social structure, the employer's policies, the attitudes of workers in front of technical changes, the market and the governments should be of interest to everyone concerned in the strategy of organizing and collective bargoining.

The south is changing rapidly, industrialization is coming, the particularities between the states and diminishing. The main characteristics of the period to come are a speedy economic development, increased membership among white collars and qualified workers.

This study will be of great interest to both students and experts in labor relations because it gives more than an historical approach, but a sociological, economic and juridical outlook of the problems in labor organization. This history is not a theorical one definitely; it is the result of a rich experience in the field. That is why it does not have narrow perspectives, but a national and international value.

\section{L.-René PARENTEAU}

L'Animation, Cahiers de I'I.C.E.A., nos 4-5, septembre 1967, $187 \mathrm{pp}$.

"Qui n'a pas entendu parler d'animation et d'animation sociale? La publicité n'est plus à faire à ce sujet. Cependant il importe de dépasser les mots et de découvrir les réalités qu'ils recouvrent. Car la popularité risque, trop souvent, de noyer l'essentiel. "

Le temps semble venu de faire le point sur cette question et de clarifier ce qu'on 